See discussions, stats, and author profiles for this publication at: https://www.researchgate.net/publication/319251084

\title{
Making Compatible Energy Planning with Urban Decision-Making: Socio- Energy Nodes and Local Configuration
}

Conference Paper in Lecture Notes in Electrical Engineering · March 2018 DOI: $10.1007 / 978-3-319-58172-9 \_7$

\section{CITATION}

1

2 authors:

Gilles Debizet

Université Grenoble Alpes

77 PUBLICATIONS 142 CITATIONS

SEE PROFILE
Antoine Tabourdeau

EIFER, European Institute for Energy Research

25 PUBLICATIONS 46 CITATIONS

SEE PROFILE

Some of the authors of this publication are also working on these related projects:

Project Grenoble Interdisciplinary Days View project

Project OUI-GEF (Outils innovants pour une gestion concertée des forêts) View project 


\title{
Author's version of the paper
}

Debizet G., Tabourdeau A. (2018) Making Compatible Energy Planning with Urban Decision-Making: Socio-Energy Nodes and Local Configuration. In: Bessède JL. (eds) Eco-design in Electrical Engineering. ED2E 2017. Lecture Notes in Electrical Engineering, vol 440. Springer, Cham

- DOI https://doi.org/10.1007/978-3-319-58172-9_7

- Publisher Name Springer, Cham

- Print ISBN 978-3-319-58171-2

- Online ISBN 978-3-319-58172-9

- eBook Packages Engineering

\section{Making compatible energy planning with urban decision-making}

\section{Socio-Energetic Nodes and geographic configurations}

Gilles Debizet

Univ. Grenoble Alpes, PACTE, F-38000 Grenoble, gilles.debizet@ujf-grenoble.fr

Antoine Tabourdeau,

CNRS, PACTE, F-38000 Grenoble, France, antoine.tabourdeau@gmail.com

\begin{abstract}
This communication will develop a specific concept, the socio-energetic node (SEN), to help understand energy assemblages in urban spaces. The SEN concept broadens the scope of planning to urban-energy interaction, the better to understand three main points. First, it informs questions about how to upgrade large energy networks and hybridize them with self-sufficient energy loops. Second, it reveals elements of energy socio-technical regimes that stimulate or hamper urban energy transition. Lastly, it aims to provide support for energy planners when modelling multi-actor energy systems. We therefore emphasize the importance of qualifying relationships between energy and urban-planning stakeholders and propose a method for implementing - and reconsidering - energy planning in cities, by breaking energy systems down into SENs and by studying how they "plug into" geographic configurations.
\end{abstract}

KEYWORDS : Planning, stakeholders, renewable energies, socio-technical regimes, eco-district

\section{INTRODUCTION}

In France, the eco-district has gained popularity in the last 15 years as a sustainable concept for implementing low-carbon and renewable energy standards in urban planning. The notion widens the range of technologies for decision-makers and is required for construction stakeholders to combine their skills with these new technologies.

Energy transition has largely been scrutinized from a technological or sectoral perspective: the technological perspective focuses on the engineering and economic performance of renewable energies and low carbon technologies, through technical and econometric models, and somehow neglects the socio-technical dimension of urban approaches. This "technological fix" (Truffer and Coenen 2012) leads to viewing stakeholders as one of the main "barriers" for the deployment of technologies (Soshinskaya et al. 2014) in a determinist approach. Over the last three decades, Science and Technology Studies (STS) have underlined the "social construction 
of technology" (Pinch and Bijker 1987) and developed arguments towards a pragmatic posture, including the co-evolution of organizational forms and technologies (Truffer and Coenen 2012). Applied to the urban context, the co-shaping of cities and energy has been underlined, especially through a special issue of Urban Studies (Rutherford and Coutard 2014). This paradigmatic shift in the understanding of innovation led authors to develop intermediary objects to underline a "missing organizational context" (Bulkeley, Broto, and Maassen 2014), characterized by problems of mis-alignment between scales of socio-technical systems and government, regulation, productions of norms, experiments, etc.

Based on the Socio-Energetic Node (SEN), this communication investigates the conditions in which energy technologies were integrated in eco-districts, we substantiate different geographic configurations for sustainable urban energy and, therefore, for urban energy networks. This paper concludes with propositions regarding the compatibility of energy planning with urban development and its stakeholders.

\section{Definition of a SEN}

District heating, solar panels on top of buildings, geothermal heat pumps or biomass heating inside buildings or small hydroelectric systems cannot be considered as a part of the incumbent energy networks since the energy sources and the decision-makers differ from the large historical technical systems (Coutard and Rutherford 2013). For the same reason they usually cannot be considered as an extension of building energy systems either. Hence, we suggest to treat these elements as all or part of a Socio-Energetic Node (SEN).

A SEN is a group of physical elements which collect, convert and/or supply energy and are built by the same decision-maker (Debizet et al. 2016) in interaction with other stakeholders and social and technical rules. District heating systems are not the only kind of SEN: internal building supply chains (electricity and heat or gas) are built by the same decision-maker (a real estate company), so they may be seen as two other SENs (one for electricity and one for heat). Both public and private networks can be considered as SENs too, connected to other SENs. Therefore, groups of SENs make up the energy system(s) of the city. It is important to underline that the SEN idea is distinct from innovation: within a SEN, there can be either no specific innovation or deep changes.

The SEN idea is based on socio-technical concepts like the Actor-Network Theory. The SEN is partly located within one or more energy-supply chains (energy flows) and it is a project led by a decision-maker interacting with human and non-human actants.

\section{Theoretical background in energy and urban planning literature}

Energy transitions involve multiple innovations in energy and urban planning, as well as in economic and managerial studies. Perspectives such as the multilevel approach (Geels \& Schot 2007) focus on innovation processes but somehow neglect the integration of socio-political and socio-spatial processes (Coutard and Rutherford 2013; Truffer and Coenen 2012). The increasing weight of decentralized renewable energies requires these processes to be reconsidered. The first concern is the link between technological systems - energy networks - and socio-political considerations, particularly with regard to energy transition. The second concern is the ties between energy and cities and the third between energy planning and business.

Technological networks play an economic and social but also cultural and ideological role (Kaika and Swyngedouw 2000). Hence, large technological networks, as developed since the 19th century, have shaped urban governance. Energy infrastructure also engages the competencies and political choices of urban authorities. Changes towards more decentralized, polycentric governance models and their combination with "sustainable urban development" since the 1970s prompted Coutard and Rutherford to suggest the notion of "post-network" cities (Coutard and Rutherford 2013), engaged in new energy infrastructures, which entirely reconfigure urban operation. The SEN enable to grasp the reconfigurations of energy systems Reconciling... Debizet\&Tabourdeau 1/3/18 10:20:00 AM

Page 2 of 10 
within a place, that is with an urban-planning input. Hence, the SEN opens the black box of urban politics with regard to climate change and energy transitions, making it possible to monitor changes in urban infrastructures.

Scientific works highlight the ties between urban and energy studies: as Jaglin (2014) wrote "cities are increasingly recognized as critical arenas for addressing energy issues". This means that energy issues and urban planning are closely interlinked and cannot be understood separately. The concentrated urban energy production (which can be either injected in public networks, self-consumed or supplied) opens a wide range of options for energy management. The question was raised to distinguish which scales are more relevant to applying energy strategies (Pasimeni et al. 2014). This involves exploring unusual scales, especially intermediary between large technical network and energy end-users (and sometime producers). We would like to emphasize that the SEN is an operative tool enabling us to define the different human and non-human components interacting in energy planning processes. Our first hypothesis is that the use of renewable energies in urban areas requires us to consider intermediary scales between buildings and large technical networks.

Recent papers focus on heating demand and the key role of district heating systems for energy transition to more efficient and diversified energy systems (Kelly et al., 2010; Lund et al, 2010; Lund et al. 2014; Rocher, 2013; Holmgren, 2006). With more stringent climate policies and the necessity to reduce energy consumption in existing building blocks, the research question has moved to the economic feasibility of district heating because of possible trade-offs between energy efficiency and fossil free district heating (Harrestrup et al., 2014; Nässén et al., 2013; Gabillet P, 2015; Hawkey et alii, 2013). The second issue is electricity supply and particularly smart grids - ICT, smart meters, demand/response, storage, etc. (Orecchini et al, 2011; Crossley, 2009). The other focus concerns electricity alone with still limited research on smart energy systems taking account of heat, electricity, cooling, gas, storage, energy efficiency (Mathiesen, 2015; Lund et alii, 2014; Ramanunni et alii, 2013; Rivarolo et alii, 2013). Most of them concern the global (national) level or a specific project but some authors are clearly interested in the possibilities offered by smart energy systems for the supply of urban areas (Kiss, 2015) or districts with near 100\% renewable energy (Lund et alii, 2012). It therefore addresses the economic feasibility of an energy system but does not explore the social involvement and business models of each stakeholder. The diversity of resources and of geographical scales and also, the links to energy saving by consumers favour intermediaries: there could be new business models and/or new stakeholders. The business model (BM) concept enables to represent how organizations participate in such collective projects by proposing, creating and delivering value to the market. Most recent definitions of the business model assume that it comprises four elements: customer identification, customer engagement, value chain and monetization (BadenFuller \& Mangematin, 2013). The value chain of business models is usually developed according to a horizontal coordination, usually implemented in sustainable innovation (Bocken \& al. 2014). However this coordination requires agency (Genus \& Coles 2008; Boons \& Ludecke-Freund 2013), which is not an equal role for the various stakeholders. Hence the main actors of a business model mobilize a value chain including other business models with their own agencies.

Our second hypothesis is that the value chain of a business model for an urban energy system depends on other inter-connected business models. Energy planning must consequently take account of value created by the various business models in the energy supply chain (and loops).

\section{Material and method}

The climate change emergency requires rapid and local changes in energy supply. We have focused on energy innovations in eco-districts. The present work used eco-district case studies to identify changes in energy planning practices.

The eco-district idea gradually took shape at the end of the 20th century. The Aalborg Charter in Reconciling... Debizet\&Tabourdeau 1/3/18 10:20:00 AM

Page 3 of 10 
1994 was a turning point in its definition and recognition (Boutaud 2009; Souami 2011). The idea is widely used in French-language literature, especially since the French ministry of environment initiated the "EcoQuartier" award in 2009. The eco-district brings sustainable development principles into urban planning, by integrating energy efficiency, use of renewable energies, ecological improvements, etc. Eco-district is a plastic term encompassing many practices and allowing us to question urban planning. In France the eco-district concept is used as a planning concept for districts delivering social and environmental standards, which otherwise face blockage by some stakeholders.

We conducted this analysis as part of the NEXUS project, funded by the French Energy and Environment Agency (ADEME) ${ }^{1}$. The operational target was to design urban energy coordination scenarios for 2040, considering the development of renewable energies, especially the management of their intermittencies (Debizet et al. 2014; Debizet and Blanchard 2015; Debizet, 2016). The diversity of actors requires a diversity of disciplines to include specific operational notions (business models, urban planning, energy policies, etc.).

Beforehand, a bibliographical survey was carried out, allowing us to identify about 12 ecodistricts presenting strong commitment to renewable energies (Blanchard and Debizet 2015). We sampled a diversity of low-carbon technologies (biomass, photovoltaic, geothermic, CHP, sewage-water heat recovery, etc.) (Schneuwly and Debizet, 2015).

Twenty interviews were conducted at the De Bonne eco-district (Grenoble): local authority representatives, town and energy planners, urban project managers, architects and energy consultants, local energy operators and, for four building projects, developers, architects, energy consultants and representatives of residents. De Bonne urban project includes 800 residential units, a shopping and leisure centre, school and several residential services for senior citizens, students and tourists. It received awards from the European Concerto programme in 2005 and the French Government in 2009 for its early energy performance and variety of energy resources, especially an innovative CHP located inside buildings (Figure 1).

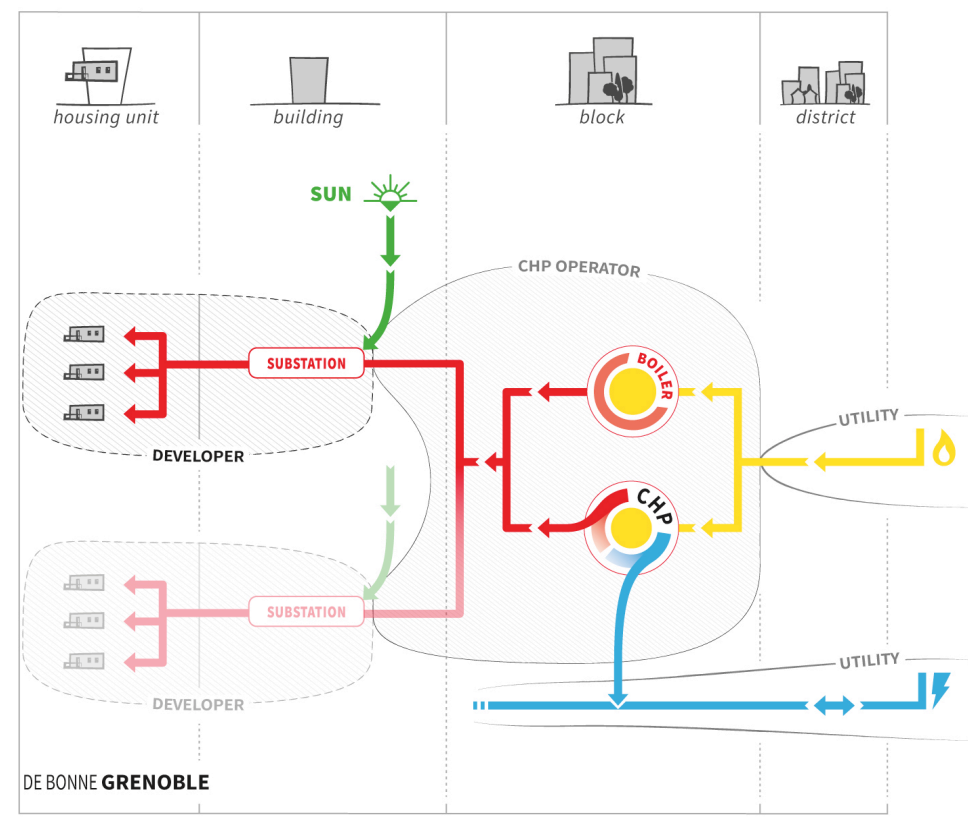

Figure 1 CHP Socio-Energetic Node, De Bonne, Grenoble, France

Five interviews were carried out at each of three other eco-districts. In Fontaine and Nanterre, we

1 This article mobilizes results of the research project « Ecoquartier NEXUS Energie » (Eco-district NEXUS energy), cofunded by ADEME (French Environment and Energy Management Agency), and led by the laboratory PACTE-CNRS

(coordination Gilles DEBIZET), the federative research structure INNOVACS, the laboratory EDDEN (UPMF), the INES (CEA) and Grenoble Ecole de Management: http://www.nexus-energy.fr/ 
interviewed municipality representatives and directors, energy consultants and/or the energy contractor, project manager and building developer. Bastille is an urban regeneration project located at Fontaine, a suburb of Grenoble. Several new social housing buildings, a refurbished condominium, new streets and district heating supplied by a wood-fired heating plant make up this project (figure 2). Sainte-Geneviève is a new development on a former industrial site located at Nanterre, a suburb of Paris. Six hundred residential units consisting of residential real estate and social housing are connected to a heating network supplied by a plant using wastewater and geothermic probes (figure 2).

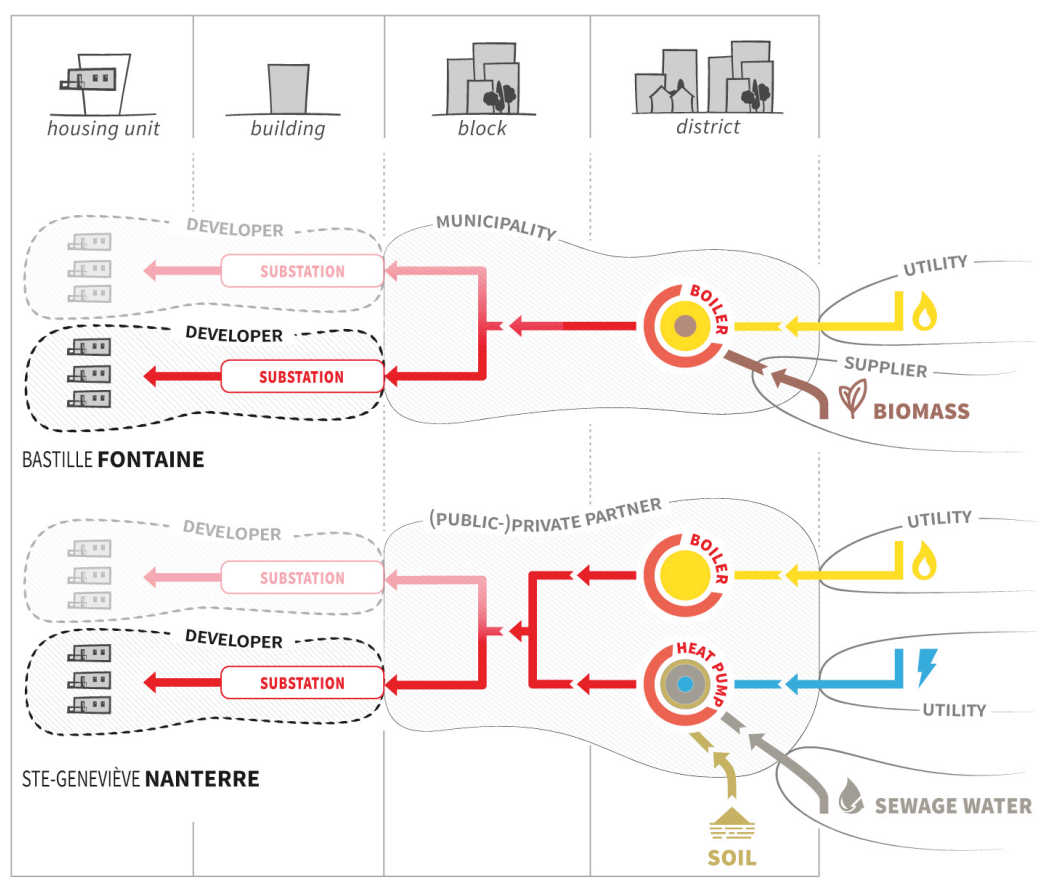

Figure 2, District heating SENs, Fontaine and Nanterre, France

The fourth case study was Issy Grid, a smart grid experiment led by several companies located in a district of Issy-le-Moulineaux, a suburb of Paris. The companies are working together to experiment with information and virtual flows between their office buildings (as long as they themselves are not allowed to buy or sell power). The experiment includes PV panels, car battery storage connected to the electric grid of an office building (figure 3), and mitigation of consumption peaks by associating office and residential buildings. We interviewed the main stakeholders of this voluntary collaborative smart grid. 


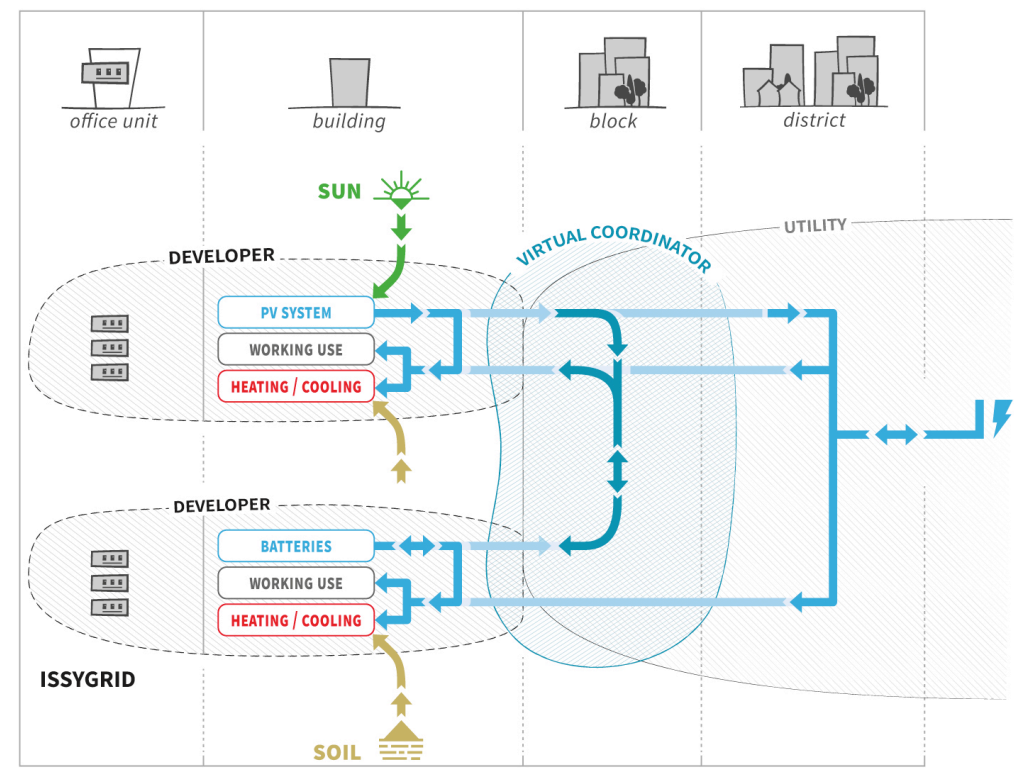

Figure 3 Smart Grid vrtual SEN, Issy, France

\section{Results: SEN as an intermediary between geographic configurations}

A determinist approach to planning such as the techno-economist posture described in our theory section (2) cannot successfully implement innovative urban solutions because it makes no allowance for the ability to produce different assemblages. How an unusual energy resource could be activated? Which organizations an energy-planner should take into account before technical and economic modelling?

The SEN highlights interaction between standards, networks and stakeholders. The nature of such interaction differs, but each instance shapes energy planning. Through the intermediary approach, (Moss et al. 2011) underline the need for intermediaries "between this triad of provider, regulator and user". The SEN bridges not only physical networks like traditional large networks and new local networks, but also provides an outlook on these different types of interaction and how they are put together. We shall therefore propose several operational categories of connections based on an intermediary SEN. 

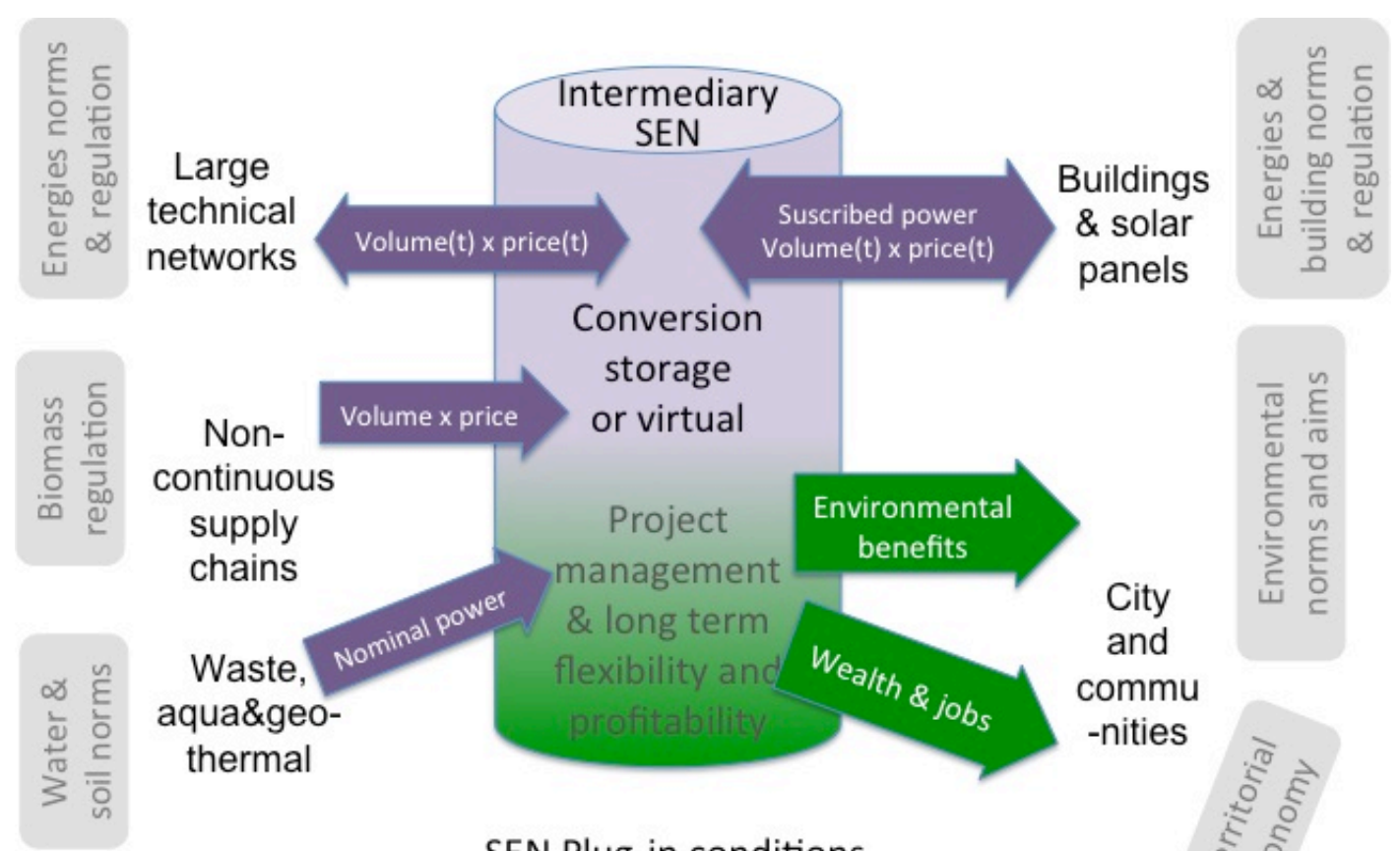

SEN Plug-in conditions

\section{Figure 4 : Intermediary SEN and geographic configurations}

Our results underlined that five different types of geographical configurations can be connected to a SEN, as shown in figure [4]: 1) large technical networks, 2) buildings and solar panels, 3) non-continuous supply chains, 4) waste and geothermal resources, 5) cities and communities. These five types of configurations have different governance modes, which specifically shape the intermediary SEN (centre of figure 4).

1) Large technical networks convey energy to the SEN, mainly from outside resources e.g. nuclear electricity, gas, and, to a lesser extent, from local resources, e.g. solar and solid waste incineration. These networks comply with specific energy standards and regulations defined at state level.

2) Buildings are places for consumption. In this configuration, developers and owners are the main decision-makers and conform to local urban regulations and buildings standards regarding connections to large technical systems. The developer usually builds the energy systems inside a building and rooftop solar panels. Hence, the intermediary SEN (centre figure 4) is connected to numerous SENs (inside buildings).

3) In non-continuous supply chains (mainly biomass), the resource is conveyed in its original form (wood) to its place of consumption and then converted into heat in a boiler. Users buy volumes of energy instead of power. There is no wood-energy sector as such in France (Tabourdeau 2014), hence stakeholders belong to very different socio-political arenas and are not subject to powerful public regulation since the supply chain is non-continuous. Gas and fuel delivered by trucks encounters the same issues. A such supply chain could considered as a SEN.

4) Wastewater and geo-thermal heat recovery are usually located close to the SEN since conveying heat over long distances is expensive. Heat transfer is limited by the rated power capacity. Extracting heat from wastewater depends on the waste collection network. Geothermal rated power requires the approval of local/regional authorities, in line with state environmental standards and procedures. A system of this sort is generally a part of the intermediary SEN (centre of figure 4).

5) SENs interact with cities and communities through economic and environmental effects. The use of local and renewable energies instead of fossil fuel (or remotely generated electricity) is a means of creating jobs and retaining wealth locally, while preventing air pollution. Avoiding 
GHG emissions is also a way of demonstrating solidarity with the global community. The local authority approves (or not) the implementation the intermediary SEN and affects its design.

By connecting these configurations, the intermediary SEN has both economic (labour, capital) value and environmental impacts (GHG and particle abatement). Even if it is usually part of an energy supply chain, it interconnects with several geographic configurations. These two notions - SEN and geographic configuration - may help planners to combine energy transition and urban planning.

\section{Conclusion: Reconciling energy planning with urban decision-making}

This paper proposes energy planning methods, drawing on the SEN concept. For each project these methods enable energy planners to reconcile business models (BM) leading a sustainableenergy project with other SENs and geographic configurations. Neither the city nor its energy systems can be built using determinist top-down planning; both require assemblages and transformations. This tendency is being reinforced by the massive development of decentralized renewable energies. A pragmatic posture is consequently needed.

Thanks to the SEN concept the various components involved in assemblages can be identified in two main ways: 1) the SEN concept identifies each energy system; 2) the SEN identifies the artefacts and stakeholders, which will interact with the SEN project.

1) The business model allows us to understand the point of view of decision-makers and projectleaders, who could apply economical methods based on return on investment: our results show the need to re-think these methods since organizations participate in SEN projects to gain rewards, which are not just economic, suggesting that the BM concept should be enlarged beyond simply being concerned about financial model elements. This study shows that noneconomic benefits - such as appearing concerned by environmental, or local employment issues - are driving renewal of the BM and deserve greater attention. Both those economic and noneconomic benefits are embedded in different value networks, which interact with the different geographical configurations described above, impacting on business model (Gauthier, Blanco, and Jullien, 2015).

2) Then it is necessary to integrate stakeholders and artefacts interacting with a project leader, in order to provide relevant potential energy resources and implement political, economic and territorial issues. The five types of SEN or geographical configurations are seldom all in interaction at the same time (more often two or three) but identifying which are interacting in a given SEN makes it possible to specify and integrate the project environment and constraints for planners. Thanks to the SEN co-shaping of urban infrastructures and energy transitions can be illustrated and made operational.

Leadership and inter-cooperation between organizations - via energy network regimes and urban governance modes - appear to be enabling factors for the energy transition. Defining the rules of governance is a key managerial issue for energy projects wishing to design sustainable SENs. As for urban projects; the SEN highlights energy-planning implementation.

\section{Acknowledgements}

Authors thank Ademe (French Environment and Energy Management Agency) for funding the Ecoquartier Nexus Energy research project led by PACTE laboratory (CNRS, IEP, Université Grenoble Alpes) in partnership with EDDEN, Innovacs (University Grenoble Alpes), INESCEA-Tech and Grenoble School of Management. See www.nexus-energy.fr

\section{References}

1. Blanchard, O. and Debizet G. "Écoquartier, systèmes énergétiques et gouvernance : une base de données bibliographique." Innovatio, No. 2. 2015. 
2. Bocken, N.M.P., Short, S.W., Rana P. \& Evans S. "A literature and practice review to develop sustainable business model archetypes.” Journal of Cleaner Production, Vol. 65, pp. 42-56. 2014.

3. Boons, F. \& Lüdeke-Freund, F. "Business models for sustainable innovation: state-of-the-art and steps towards a research agenda". Journal of Cleaner Production, Vol. 45, pp 9-19. 2013.

4. Boutaud, B. "Quartier durable ou éco-quartier ?” Cybergeo : European Journal of Geography, September. 2009.

5. Bulkeley, H., Castán Broto V. and Maassen A. "Low-Carbon Transitions and the Reconfiguration of Urban Infrastructure." Urban Studies Vol. 51, No. 7, pp 1471-86. 2014.

6. Coutard, O. and Rutherford J. "Vers L'essor de Villes «post-Réseaux»: Infrastructures, Innovation Sociotechnique et Transition Urbaine En Europe.” In L'innovation Face Aux Défis Environnementaux de La Ville Contemporaine, Presses Polytechniques Universitaires Romandes. Forest J. et Hamdouch A. 2013.

7. Crossley P, Beviz A. "Smart energy systems: transitioning renewables onto the grid", Renewable Energy Focus Vol. 11, 2009.

8. Debizet, G., "Scénarios de transition énergétique en ville. Acteurs Régulations Technologies" La Documentation Française, 200p., 2016

9. Debizet, G. and Blanchard. O. "Énergies en (éco)quartier.” Innovatio, no. 2. 2015.

10. Debizet, G. Gauthier C., Labranche S., Menanteau P., Ambroise-Renault V., Blanchard O., Blanco S., et al. "Energy Coordination in Eco-Districts: The Multi-Disciplinary NEXUS Project". In Proceedings of the 9th Conference on Sustainable Development of Energy, Water and Environment Systems. Venice-Istambul, SDEWES2014.0295 P. 1-16.” 2014.

11. Gabillet P. "Energy supply and urban planning projects: Analysing tensions around district heating provision in a French eco-district", Energy Policy Vol. 78, pp189-197, 2015.

12. Gauthier, C., Blanco S., and Jullien. C. "Écoquartiers et nœuds socio-énergétiques : transformation des modèles d'affaires." Innovatio, No. 2. 2015.

13. Genus, A. \& Coles, A. "Rethinking the multi-level perspective of technological transitions. Research Policy, Vol. 37, No. 9, pp 1436-1445. 2008.

14. Harrestrup M., Svendsen S. "Heat planning for fossil-fuel-free district heating areas with extensive end-use heat savings: A case study of the Copenhagen district heating area in Denmark", Energy Policy Vol. 68, 2014.

15. Holmgren, K. "Role of a district-heating network as a user of waste-heat supply from various sources: the case of Göteborg", Applied Energy, Vol. 83, 2006.

16. Kelly,S., Pollitt,M., "An assessment of the present and future opportunities for combined heat and power with district heating (CHP-DH) in the United Kingdom", Energy Policy Vol. 38. 2010 .

17. Kiss V. M., « Modelling the energy system of Pécs - The first step towards a sustainable city", Energy, Volume 80, 1 February 2015, Pages 373-387

18. Jaglin, S. "Urban Energy Policies and the Governance of Multilevel Issues in Cape Town." Urban Studies Vol. 51, No. 7, pp 1394-1414, 2014.

19. La Branche, S.“Innovations dans les écoquartiers : quelques leçons pour la gouvernance de la transition énergétique." VertigO - la revue électronique en sciences de l'environnement Innovatio, Volume 14 Numéro 3. 2015.

20. Lund H., Werner S., Wiltshire R., Svendsen S., Thorsen J.E., Hvelplund F. and Vad Mathiesen B. 2014. "4th Generation District Heating (4GDH): Integrating smart thermal grids into future sustainable energy systems", Energy, 68)

21. Lund H., Andersen A. N., Ostergaard P. A., Vad Mathiesen B. and Connolly D. "From electricity smart grids to smart energy systems: A market operation based approach and understanding", Energy Vol. 42, 2012. 
22. Lund, H., Möller,B., Mathiesen,B.V. and Dyrelund,A. 2010. "The role of district heating in future renewable energy systems", Energy 35

23. Mathiesen B.V., Lund H., Connolly D., Wenzel H., Ostergaard P.A., Moller B., Nielsen S., Ridjan I., Karnoe P., Sperling K. and Hvelplund F.K. "Smart Energy Systems for coherent 100\% renewable energy and transport solutions", Applied Energy Vol. 145, 2015.

24. Menanteau, P., and Blanchard. O. "Quels Systèmes Énergétiques Pour Les Éco-Quartiers ? Une Première Comparaison France-Europe." Revue de l'Energie, no. 622, 2014.

25. Moss, T., Guy S., Marvin S., and Medd W. "Intermediaries and the Reconfiguration of Urban Infrastructures: An Introduction." In Shaping Urban Infrastructures: Intermediaries and the Governance of Socio-Technical Networks, Earthscan. London - Washington DC: Simon Guy, Simon Marvin, Will Medd and Thimoty Moss. 2011.

26. Nässén J., Holmberg J. "On the potential trade-offs between energy supply and end-use technologies for residential heating", Energy Policy Vol. 59, 2013.

27. Orecchini F, Santiangeli A. "Beyond smart grids: the need of intelligent energy networks for a higher global efficiency through energy vectors integration", International Journal of Hydrogen Energy Vol. 36, 2011.

28. Pasimeni, M.R., Petrosillo I., Aretano R., Semeraro T., De Marco A., Zaccarelli N. and Zurlini G. "Scales, Strategies and Actions for Effective Energy Planning: A Review." Energy Policy Vol. 65, pp 165-74. 2014.

29. Pinch, T. J, and Bijker W.E . "The Social Construction of Facts and Artifacts: Or How the Sociology of." The Social Construction of Technological Systems: New Directions in the Sociology and History of Technology Vol. 17. 1987.

30. Ramanunni P. Menon, Mario Paolone, François Maréchal, Study of optimal design of polygeneration systems in optimal control strategies, Energy vol 55, 2013.

31. Rivarolo M, Greco A, Massardo A., Thermo-economic optimization of the impact of renewable generators on poly-generation smart-grids including hot thermal storage, Energy Conversion and Management vol 65. 2013.

32. Rocher L. "Le chauffage urbain dans la transition énergétique: des reconfigurations entre flux et réseau.", In Métropolis - Flux, Vol. 2 No. 92. 2013.

33. Rutherford, J., and Coutard O. "Urban Energy Transitions: Places, Processes and Politics of Socio-Technical Change." Urban Studies Vol. 51, No. 7, pp 1353-77. 2014.

34. Schneuwly, P. and Debizet. G. "Technologies de mobilisation des énergies renouvelables et de coordination énergétique dans les écoquartiers.” Innovatio, 2015.

35. Soshinskaya, M., Crijns-Graus. W. H. J., Guerrero J.M, and C. Vasquez J. "Microgrids: Experiences, Barriers and Success Factors." Renewable and Sustainable Energy Reviews Vol. 40, pp 659-72. 2014.

36. Souami, T. "Ecoquartiers secrets de fabrication. Analyse Critique d'exemples Européens." Les Carnets de l'Info. Collection « Modes de Ville », 2011.

37. Tabourdeau, A. "Entre forêt et énergie : composer la transition. Le cas du bois-énergie en Auvergne et Rhone-Alpes." PhD Doctorate, Université de Grenoble. 2014.

38. Truffer, B. and Coenen. L. "Environmental Innovation and Sustainability Transitions in Regional Studies.” Regional Studies Vol. 46, No. 1, pp 1-21. 2012. 